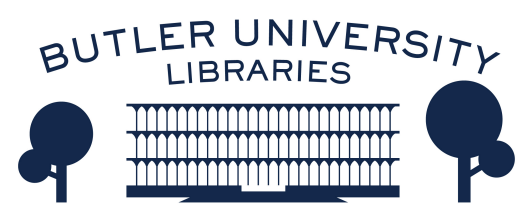

Journal of Hindu-Christian Studies

Volume 11

Article 20

January 1998

\title{
Book Review: "The Impact of Ancient Indian Thought on Christianity"
}

Braj M. Sinha

Follow this and additional works at: https://digitalcommons.butler.edu/jhcs

Part of the Religion Commons

\section{Recommended Citation}

Sinha, Braj M. (1998) "Book Review: "The Impact of Ancient Indian Thought on Christianity"," Journal of Hindu-Christian Studies: Vol. 11, Article 20.

Available at: https://doi.org/10.7825/2164-6279.1193

The Journal of Hindu-Christian Studies is a publication of the Society for Hindu-Christian Studies. The digital version is made available by Digital Commons @ Butler University. For questions about the Journal or the Society, please contact cbauman@butler.edu. For more information about Digital Commons @ Butler University, please contact digitalscholarship@butler.edu. 
sometimes and quite unnecessarily lapses into generalized statements about "all" religions which are particularly inappropriate as he only materially deals with Hinduism, e.g., pp. $35,50,60,71$ ).

The next two chapters are moving and insightful explorations of his contention that Hinduism and Christianity are at least united in "weaning us from our idolatry and purifying our desires" (p.21). He takes up the latter via a necessarily unresolved exploration of the Upanishads and Gita with many rich observations on the way. Christian and Vedantic Hinduism's commonality, reflecting Lash's healthy predilection for apophatic theology, is found in both traditions' sense of the provisonality and ambiguity regarding the question of who we are. But this is marked by the narratives within which "remembrance" and "expectation" have differing functions within each pedagogic school. So while recognizing that the theme of "Gift" (p.32) is central to both, Lash is also aware that the nature of the Gift generates different patterns, with their own enigmas and unresolved difficulties. With "Gift", this chapter is markedly Christological. The final lecture is markedly trinitarian, although Lash's relentless energy to think things freshly means that we do not stumble upon tough technical trinitarian vocabulary. One of the rich insights here, which needs far more development, is his exploration of sat-cit-ananda as a trinitarian psychological analogy.

There are details which one might contest (such as his suggestion that matterspirit dualism is alien to India and is a European Enlightenment imposition) and insights which one would wish further developed, but that is testimony to the stimulation of the lectures. My one criticism would be that despite his excellent first chapter, he nevertheless tends to treat "Hinduism" in a somewhat abstracted manner, purely in terms of the Upanishads and Gita, as if it were not, like Christianity, a schooling in the use of power and social formation. In later chapters (e.g., 12), Lash is very particular upon just this point, but in his treatment of Hinduism one gets no sense of the social and symbolic order that mediate the texts he deals with and in this sense there is a real danger of the Enlightenment reification he so carefully criticizes creeping in through the back door. But this is a danger, no more. From what Lash has offered there is much to learn, and his engaging Christian approach to the issue will be better appreciated by reading the book in its entirety.

Gavin D'Costa University of Bristol

The Impact of Ancient Indian Thought on Christianity. V. W. Deshpande. New Delhi: APH Publishing Corporation, 1996. xi +359 pp.

\author{
THE IMPACT OF Ancient Indian Thought \\ on Christianity by V. W. Deshpande is a \\ work which readers will find both \\ provocative and frustrating. It is provocative \\ in its claim that the historical contacts of the \\ Middle Eastern and Greco-Roman world \\ with India during the pre-Christian era must \\ have impacted the developments of Judeo- \\ Christian world perspectives in a significant
}

way. It is frustrating because its claims are more in the nature of tenuous hypotheses rather than definitive conclusions.

In the Introduction, the author spells out the subject matter of the book which "is to find out whether there is any impact of ancient Indian thought on the New Testament as well as in the contemporary literature of Christianity". If there is any 
impact, what is its extent, what are the reasons for it, and when did Indian thought come in contact with Israel, Greece, and Rome in ancient times to impress its thoughts upon the development of early Christian thought?

Instead of carefully weighing the evidence considered by him to be crucial to support his claims, the author makes unsupported pronouncements from the very beginning. The basic argument of the book is that any philosophical idea, religious notion, ethical ideal, or ritual practice found in the Judeo-Christian literature that is even remotely parallel to similar elements in Hinduism or Buddhism must have its source in some direct or indirect impact of ancient Indian thought on Jewish-Christian heritage during its formative period. However, a reader looking for specific historical or textual evidence to support this initial provocative thesis will find only possibilities, conjectures, and hypotheses which the author never succeeds in translating into definitive conclusions based on scholarly analysis of the material studied. Although Deshpande discovers some interesting resemblances between Christianity and ancient Indian thought, any value of this book as a comparative study is severely compromised by the author's categorical statement that if we find any resemblance between ancient Indian metaphysical thought and that of Christian scriptures "it will be logically concluded that such resemblance is due to the impact of ancient Indian thought on Christianity..." (p.79).

The book nevertheless does have a semblance of solid scholarly work and there are valuable insights into the possibilities of cross fertilization of ideas between India and the near East. There are detailed time lines, lists of documents, comparative charts, an appendix, and an impressive bibliography. Discussions of thematic affinities between ancient Indian thought and the Biblical tradition is definitely interesting and in some ways refreshing. The major flaw of Deshpande's book, however, is that thematic and structural affinities in the two major cradles of ancient civilization are presumed to be causally related, with a clear bias toward asserting both the chronological and ideological superiority of ancient Indian thought over the Biblical tradition, which is supposed to have been impacted in every possible way by Indian thought.

Braj M. Sinha

University of Saskatchewan

\section{Annai் Bahu Kurvĩta: Recollecting the Indian Discipline of Growing and Sharing Food in Plenty. Jitendra Bajaj and Mandayam Doddamane Srinivas. Madras: Centre for Policy Studies, 1996, lvi +217 pp.}

THIS BOOK WAS written with a purpose. As the title indicates, the theme is the Indian discipline of growing and sharing food in plenty. That is not "a question merely of economics, but of the essence of dharmic living" (p.xii). It is said that the inviolable discipline of sharing is what defines the essence of being Indian (p.210). At a time when people begin to reflect what it is to be
Indian and come out with different theories, this book highlights another dimension to this question of Indianness.

What is presented in this book is not a social analysis of the Indian situation, giving statistics of people living below the poverty line or the factors contributing to this situation. The emphasis is on the aspect of sharing with others. The authors establish 